\title{
C-GATE - catalogue of genes affected by transposable elements
}

\author{
Rita Rebollo ${ }^{1,2^{*}}$, Sharareh Farivar ${ }^{1,2}$ and Dixie L Mager ${ }^{1,2^{*}}$
}

\begin{abstract}
Background: Functional regulatory sequences are present in many transposable element (TE) copies, resulting in TEs being frequently exapted by host genes. Today, many examples of TEs impacting host gene expression can be found in the literature and we believe a new catalogue of such exaptations would be useful for the field.

Findings: We have established the catalogue of genes affected by transposable elements (C-GATE), which can be found at https://sites.google.com/site/tecatalog/. To date, it holds $2 \overline{2} 1$ cases of biologically verified TE exaptations and more than 10,000 in silico TE-gene partnerships. C-GATE is interactive and allows users to include missed or new TE exaptation data. C-GATE provides a graphic representation of the entire library, which may be used for future statistical analysis of TE impact on host gene expression.
\end{abstract}

Conclusions: We hope C-GATE will be valuable for the TE community but also for others who have realized the role that TEs may have in their research.

Keywords: C-GATE, Co-option, Gene regulation, Exaptation, Transposable element

\section{Findings}

Regulation of gene expression is essential for the correct development of an organism, as it dictates where, when and how much of a gene transcript should be produced. Differences in gene expression patterns can also be associated with the divergence of species [1-3], suggesting that gene regulatory sequences are of primary importance in species evolution. In the last decades, we have learned that genes are complex units [4], harboring proximal but also distal regulatory elements and very often capable of producing more than one transcript through multiple promoters, alternative splicing and cryptic polyadenylation sites. There are different mechanisms that may be responsible for the origin and evolution of gene regulatory sequences: de novo synthesis; transposition (ready-to-use regulatory elements brought by sequences and spread throughout the genome); co-option of existing regulatory sequences into new functions; and mutations, deletions and duplications within existing regulatory sequences. Transposable

\footnotetext{
* Correspondence: rrebollo@bccrc.ca; dmager@bccrc.ca

'Terry Fox Laboratory, British Columbia Cancer Agency, 675 West 10th Avenue, Vancouver, BC V5Z1L3 Canada

${ }^{2}$ Department of Medical Genetics, University of British Columbia, Vancouver, BC, Canada
}

elements (TEs) are DNA sequences able to jump throughout the genome and increase in copy number. Through transposition, TEs have a direct impact on genome size and therefore increase the genetic repertoire, which in consequence may be the target of de novo evolution. Furthermore, TEs have ready-to-use regulatory sequences that may be exapted as promoters and enhancers, binding sites, splice sites, polyadenylation signals, insulators and termination sites. Since some TE families are species-specific, TEs could also account for species-specific regulatory sequences. In agreement with this, the number of examples of TEs impacting host gene expression is increasing in the literature, particularly with the advent of genome-wide next-generation sequencing technologies. For instance, several groups have found transcription start sites in mammals to be frequently positioned within TE sequences [5-7]. While the search for conserved regulatory elements is able to demonstrate ancient waves of TE insertions that have contributed to regulatory sites $[8,9]$, comparisons between species-specific regulatory sequences show that recent TE transpositions have also donated new regulatory elements to different species $[9,10]$. Interestingly, TE families and copies may colonize different species genomes but act as equivalent gene regulatory sequences, as observed with the 
Table 1 Examples of C-GATE

\begin{tabular}{|c|c|c|c|c|c|c|c|c|c|c|c|}
\hline Species & $\underset{*}{\text { Type }}$ & Family & Subfamily & $\begin{array}{l}\text { Regulatory } \\
\text { effect * }\end{array}$ & Comments * & Gene * & $\begin{array}{l}\text { Gene regulatory } \\
\text { networks }\end{array}$ & $\begin{array}{l}\text { Environment } \\
\text { response? }\end{array}$ & $\begin{array}{c}\text { Date of } \\
\text { publication * }\end{array}$ & Reference $(1) *$ & Reference (2) \\
\hline $\begin{array}{l}\text { Latin } \\
\text { name }\end{array}$ & $\begin{array}{l}\text { LTR, LINE, } \\
\text { SINE, } \\
\text { DNA }\end{array}$ & TE family & $\begin{array}{l}\text { TE sub- } \\
\text { family }\end{array}$ & $\begin{array}{l}\text { How does the } \\
\text { TE impact the } \\
\text { gene? }\end{array}$ & $\begin{array}{l}\text { A clear summary of the publication and/or } \\
\text { details on the exaptation event. }\end{array}$ & $\begin{array}{l}\text { Gene with the } \\
\text { TE exaptation }\end{array}$ & $\begin{array}{l}\text { Is the TE or gene } \\
\text { part of a } \\
\text { regulatory } \\
\text { network? }\end{array}$ & $\begin{array}{c}\text { Is the exaptation a } \\
\text { response to } \\
\text { environment } \\
\text { changes? }\end{array}$ & & $\begin{array}{l}\text { Reference with a } \\
\text { link to the journal }\end{array}$ & $\begin{array}{l}\text { Second } \\
\text { reference if } \\
\text { necessary }\end{array}$ \\
\hline $\begin{array}{l}\text { Homo } \\
\text { sapiens }\end{array}$ & LTR & ERV-1 & HERV-9 & $\begin{array}{l}\text { Alternative } \\
\text { promoter }\end{array}$ & $\begin{array}{c}12 \% \text { of NAIP total expression in testis is due } \\
\text { to a LTR9. }\end{array}$ & NAIP & & & 2007 & $\begin{array}{l}\text { Romanish et al. } \\
\text { (2007) PloS } \\
\text { Genetics [11] }\end{array}$ & \\
\hline $\begin{array}{l}\text { Homo } \\
\text { sapiens }\end{array}$ & LTR & ERV-3 & Mer74C & $\begin{array}{l}\text { Primary } \\
\text { promoter }\end{array}$ & $\begin{array}{l}\text { Bioinformatic analysis of human and mouse } \\
\text { RefSeq UTRs. CA1 is transcribed through } \\
\text { two promoters one of which is a LTR copy, } \\
\text { present in both human and mouse that } \\
\text { confers erythroid specific expression in } \\
\text { both species. Chimeras were confirmed } \\
\text { through bibliography or RT PCR. } \\
\text { Coordinates are from hg18. }\end{array}$ & 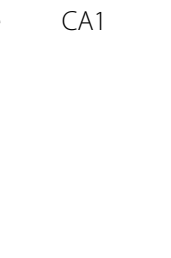 & & & 2003 & $\begin{array}{l}\text { Van de } \\
\text { Lagemaat et al. } \\
\text { (2003) Trends } \\
\text { Genet [18] }\end{array}$ & $\begin{array}{c}\text { Piriyapongsa } \\
\text { et al. (2007) } \\
\text { BMC Genomics } \\
{[19]}\end{array}$ \\
\hline
\end{tabular}

* Mandatory field.

Note that columns containing coordinates of the TE, its position relative to the gene and any influence on phenotype have been omitted for clarity but are present in C-GATE. 


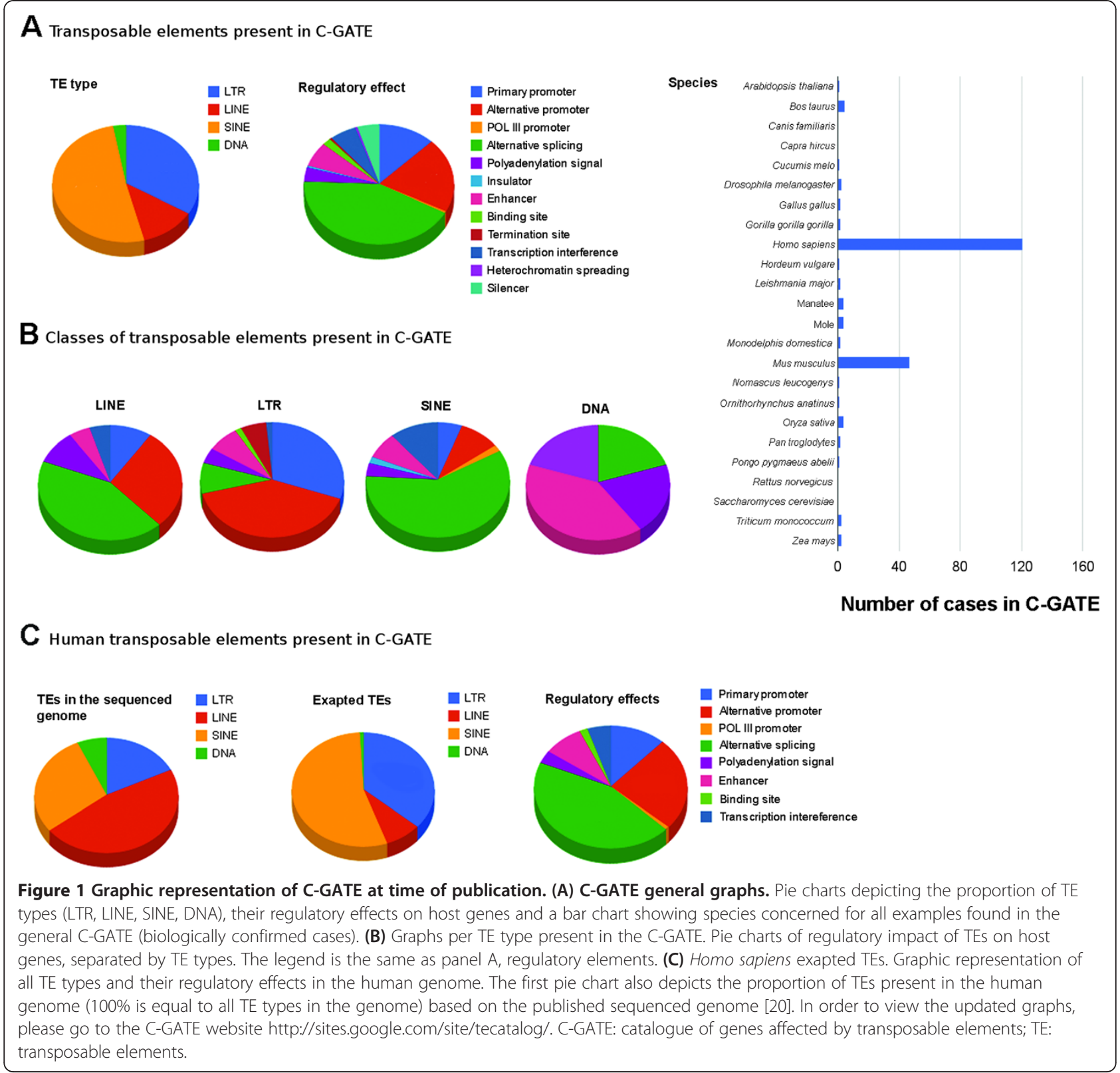

convergent evolution of NAIP promoters in mouse and human for example [11].

Because of the large amount of data on TE exaptations present in the literature today, including lists in large non-ergonomic supplementary tables, we have decided to create an online database that catalogues published examples of TE exaptations allowing for researchers to easily browse the data. The catalogue of genes affected by transposable elements (C-GATE) is available at https://sites.google.com/site/tecatalog/. We thank the efforts of others to catalogue such exaptations, in particular Brosius [12] and Makalowski [13] and other groups $[7,14]$. While these data-sets are informative, those cited in the work of Brosius and of Makalowski are out-of-date, and none are interactive and therefore do not allow for user input and updates. We have intentionally designed C-GATE to be interactive so that any missed or new examples of TEs influencing host gene expression can be easily added by any investigator in the field. All submitted new exaptation events will be analyzed for integrity and significance before being added to C-GATE. Furthermore, the catalogue can be filtered and is searchable, making it easy to take advantage of the entire data set. Users are also able to download the whole catalogue.

It is important to note that another currently active online catalogue of TE exaptations exists, TranspoGene [15], which is based on an in silico analysis of seven 
vertebrates and invertebrates species. While TranspoGene remains an interesting resource for genome-wide impact of TE copies, it does not contain TE exaptations described in the literature, but solely examples observed by the authors, at the time of their analysis. C-GATE contains all the data on exaptation available at TranspoGene but also aims to include all exaptation events described in the literature. Furthermore, CGATE contains two types of data, a general C-GATE data-set that holds only biologically confirmed and published TE exaptation examples, and a pC-GATE that holds data-sets of putative TE exaptations from ESTs, chromatin immunoprecipitation sequencing and other published in silico-only analyses. In order to be part of C-GATE, a TE exaptation needs to be observed in wild-type species, not only in mutants or cancer cell lines. TEs impacting specific inbred strains, as Drosophila melanogaster $P$ element collections, or mouse endogenous retrovirus insertions are considered as genetic mutations and not true TE exaptations. C-GATE also does not include open reading frame domestication, as described for syncytin genes for instance and often reviewed in the literature [16,17]. Depending on the usage of C-GATE and the demand of the users, a future upgrade could include such domestication events and address other user concerns.

C-GATE is formatted as shown in Table 1, and each user can either upload an example through an online form or multiple examples by downloading a table and submitting it in the C-GATE forum. A 'comment' section allows for more descriptive information regarding the publication, facilitating user comprehension of each case hosted within the catalogue. The website also holds graphic visualization of the general C-GATE data-set that is automatically updated with every new entry uploaded (Figure 1). Such graphic representations might be useful in the future to access exaptation frequency between TEs. Today, the catalogue shows a biased representation of human and mouse examples, which we hope will decrease with usage. For instance, almost 4,000 human genes are present in both C-GATE and pC-GATE. At the time of publication C-GATE, although incomplete, holds 221 cases previously described in the literature and our pC-GATE harbors more than 10,000 examples. We reinforce the notion that C-GATE is not complete and many already published TE exaptation examples are still to be included and we hope users will participate in this task. We want this database to help researchers obtain information on particular $\mathrm{TE}$ sequences or determine if their gene of interest is controlled by a TE copy. We invite researchers to discuss the catalogue on the forum present in C-GATE and we also expect many new examples of exapted TEs to be inserted by the users in the near future.

\section{Abbreviations}

C-GATE: catalogue of genes affected by transposable elements; EST: expression sequence tag; PC-GATE: putative C-GATE; TE: transposable elements.

\section{Competing interests}

The authors declare that they have no competing interests.

\section{Authors' contributions}

RR designed the website. RR, SF and DM included cases to the website. RR and DM wrote the paper. All authors read and approved the final manuscript.

\section{Acknowledgments}

We thank B. Lai for suggesting the name of the catalogue and other members of our laboratory for useful discussions. Work in our laboratory is supported by a grant from the Canadian Institutes of Health Research with core support provided by the British Columbia Cancer Agency.

Received: 3 February 2012 Accepted: 20 April 2012

Published: 23 May 2012

\section{References}

1. Levine $M$, Tjian R: Transcription regulation and animal diversity. Nature 2003, 424:147-151.

2. Wray GA: The evolutionary significance of cis-regulatory mutations. Nat Rev Genet 2007, 8:206-216.

3. Lowe CB, Kellis M, Siepel A, Raney BJ, Clamp M, Salama SR, Kingsley DM, Lindblad-Toh K, Haussler D: Three periods of regulatory innovation during vertebrate evolution. Science 2011, 333:1019-1024.

4. Gerstein MB, Bruce C, Rozowsky JS, Zheng D, Du J, Korbel JO, Emanuelsson O, Zhang ZD, Weissman S, Snyder M: What is a gene, post-ENCODE? History and updated definition. Genome Res 2007, 17:669-681.

5. Faulkner GJ, Kimura Y, Daub CO, Wani S, Plessy C, Irvine KM, Schroder K, Cloonan N, Steptoe AL, Lassmann T, Waki K, Hornig N, Arakawa T, Takahashi H, Kawai J, Forrest AR, Suzuki H, Hayashizaki Y, Hume DA, Orlando V, Grimmond SM, Carninci P: The regulated retrotransposon transcriptome of mammalian cells. Nat Genet 2009, 41:563-571.

6. Marino-Ramirez L, Lewis KC, Landsman D, Jordan IK: Transposable elements donate lineage-specific regulatory sequences to host genomes. Cytogenet Genome Res 2005, 110:333-341.

7. Cohen CJ, Lock WM, Mager DL: Endogenous retroviral LTRs as promoters for human genes: a critical assessment. Gene 2009, 448:105-114.

8. Bejerano G, Lowe CB, Ahituv N, King B, Siepel A, Salama SR, Rubin EM, Kent WJ, Haussler D: A distal enhancer and an ultraconserved exon are derived from a novel retroposon. Nature 2006, 441:87-90.

9. Schmidt D, Schwalie PC, Wilson MD, Ballester B, Goncalves A, Kutter C, Brown GD, Marshall A, Flicek P, Odom DT: Waves of retrotransposon expansion remodel genome organization and CTCF binding in multiple mammalian lineages. Cell 2012, 148:335-348.

10. Bourque $G$, Leong B, Vega VB, Chen $X$, Lee $Y L$, Srinivasan KG, Chew JL, Ruan $Y$, Wei CL, Ng HH, Liu ET: Evolution of the mammalian transcription factor binding repertoire via transposable elements. Genome Res 2008, 18:17521762.

11. Romanish MT, Lock WM, van de Lagemaat LN, Dunn CA, Mager DL: Repeated recruitment of LTR retrotransposons as promoters by the anti-apoptotic locus NAIP during mammalian evolution. PLoS Genet 2007, 3:e10.

12. Brosius J: RNAs from all categories generate retrosequences that may be exapted as novel genes or regulatory elements. Gene 1999, 238:115-134.

13. Makalowski W: Genomic scrap yard: how genomes utilize all that junk. Gene 2000, 259:61-67.

14. Oliver KR, Greene WK: Mobile DNA and the TE-thrust hypothesis: supporting evidence from the primates. Mob DNA 2011, 2:8.

15. Levy A, Sela N, Ast G: TranspoGene and microTranspoGene: transposed elements influence on the transcriptome of seven vertebrates and invertebrates. Nucleic Acids Res 2008, 36:D47-D52.

16. Feschotte C, Pritham EJ: DNA transposons and the evolution of eukaryotic genomes. Annu Rev Genet 2007, 41:331-368.

17. Volff JN: Turning junk into gold: domestication of transposable elements and the creation of new genes in eukaryotes. Bioessays 2006, 28:913-922. 
18. Van de Lagemaat $L N$, Landry JR, Mager DL, Medstrand P: Transposable elements in mammals promote regulatory variation and diversification of genes with specialized functions. Trends Genet 2003, 19:530-536.

19. Piriyapongsa J, Polavarapu N, Borodovsky M, McDonald J: Exonization of the LTR transposable elements in human genome. BMC Genomics 2007, 8:291.

20. Lander ES, Linton LM, Birren B, Nusbaum C, Zody MC, Baldwin J, Devon K, Dewar K, Doyle M, FitzHugh W, Funke R, Gage D, Harris K, Heaford A,

Howland J, Kann L, Lehoczky J, LeVine R, McEwan P, McKernan K, Meldrim J, Mesirov JP, Miranda C, Morris W, Naylor J, Raymond C, Rosetti M, Santos R, Sheridan A, Sougnez C, et al: Initial sequencing and analysis of the human genome. Nature 2001, 409:860-921.

doi:10.1186/1759-8753-3-9

Cite this article as: Rebollo et al: C-GATE - catalogue of genes affected by transposable elements. Mobile DNA 2012 3:9.

\section{Submit your next manuscript to BioMed Central and take full advantage of:}

- Convenient online submission

- Thorough peer review

- No space constraints or color figure charges

- Immediate publication on acceptance

- Inclusion in PubMed, CAS, Scopus and Google Scholar

- Research which is freely available for redistribution 